\title{
Being and Performing the Masculinity in Karim Raslan's Go East
}

\author{
Collin Jerome \\ Centre for Language Studies, Universiti Malaysia Sarawak, \\ 94300 Kota Samarahan, Sarawak, Malaysia \\ e-mail: jcollin@cls.unimas.my; C.Jerome@sussex.ac.uk
}

\begin{abstract}
This paper explores the concept of being and performing masculinity in Karim Raslan's short story Go East. Torn between being a man in his own terms and performing socially endorsed masculine roles and sexual desires, the protagonist, Mahmud, negotiates and transgresses gender borders, resulting in his inability to sexually perform with women and incapacity for emotional and physical intimacy with men. Yet, he overcomes his impotence through heterosexual intercourse despite imagining making love to men.
\end{abstract}

Key words: masculinity, male homosociality, homosexuality, homoeroticism, gender borders

Male masculinity is complex and fluid. Connell discerned that masculinity, or more specifically (Western) hegemonic masculinity "encapsulate [s] both the diversity and potential fluidity of the processes involved in men being men" (quoted in Pease and Pringle, 2001, p. 2). However, this concept does not represent other forms of masculinities, for instance, the non-Western and non-hegemonic forms. This may have contributed to Connell's idea on a global expansion of researches on men and masculinities that would represent more diverse, complex and fluid forms of masculinities from around the world. The only setback to this is the relatively small and inadequate number of researches on the subject matter that have been carried out in Asia. ${ }^{1}$

The dearth of research in this area especially in the Southeast Asian countries is readily informed by, among others, the lack of concern over gender and sexuality issues in Malaysia. ${ }^{2}$ On similar note, men in

\footnotetext{
${ }^{1}$ See Taga (2004), for a review on men and masculinities studies in East Asia.

${ }^{2}$ See Peletz (1996), for his analysis on reason and passion, and the representation of gender in Malay society.
} 
Indonesia have no complaints about their masculinity while representations of men and masculinity in print and new media have not been actively discussed or analysed (Clark, 2004). This is in contrast to the increasing body of research on men and masculinities in the Western academia (see Brod, 1987; Connell, 1987; Kimmel, 1987; Kaufmann, 1987; Hearn, 1987). Local forms of masculinities are still largely and readily defined by socio-cultural and religious values. However, in the age of information technology and globalising effects of westernisation and modernisation, these values are clearly contested and violated. This can be seen in the use of cyberspace, particularly online social network services ${ }^{3}$ as a borderless medium that helps articulate men's diverse gender and sexual identities.

However, some men may find it difficult to be who they really want to be without denying socially endorsed values relating to gender and sexuality. There are also borders or boundaries that they should not transgress, proving that it would be difficult to be a man in their own terms. These borders are informed by what is 'acceptable' and 'appropriate', and the 'right' and 'wrong' in relation to men's social roles and bodily desires, as well as men's relations with women and other men.

In this short paper, notions of borders, and being and performing the masculinity will be examined with reference to Karim Raslan's short story Go East. More specifically, the paper discusses Mahmud's unique position where he is torn between being a man in his own term and performing socially inscribed roles in sustaining his masculine identity. Mahmud is seen to be manoeuvring between being and performing the masculinity where gender borders or boundaries are negotiated and transgressed, resulting in his anxiety over his inability to sexually perform with women and incapacity for emotionally and physically intimate relationships with men.

\section{BORDERS OR BOUNDARIES}

The concept of borders or boundaries in this paper is generally based on the 'right' and 'wrong' in relation to the views about gender and sexuality. More specifically, the concept informs socially acceptable and unacceptable, as well as appropriate and inappropriate roles and bodily desires for men and women.

\footnotetext{
${ }^{3}$ See Friendster.com, Facebook.com, Fridae.com, Axcest.com
} 
The concept further informs processes of "dividing up people and social practices along the lines of sexed identities" (Beasley, 2005, p. 11) and "managing situated conduct in the light of normative constructions of attitudes and activities appropriate for one's sex category" (West \& Zimmerman, 2000, p. 132). In Boundaries, Negotiation, Consciousness: Reconceptualizing Gender Relations, Judith Gerson and Kathy Peiss discerned that the concept of gender border or boundary involves the "physical, social, ideological, and psychological which establishes the differences and commonalities between women and men, among women and among men, shaping and constraining the behaviour and attitudes of each gender group” (p. 119).

But borders or boundaries can be negotiated and resisted, blurring the male/female distinction and socially constructed relationships between men and women. This is evident in Karim Raslan's Go East where Mahmud transgresses the socially and religiously endorsed boundaries relating to heterosexual relationship in Malay Muslim society. His physical involvement with women violates the values relating to khalwat and zina. ${ }^{4}$ Additionally, his intimacy with Anton, the young boy servant transgresses the boundaries in male homosociality ${ }^{5}$ which further reveals evidence of male homosexuality and homoeroticism. It should be mentioned that Malay views about gender relations are shaped by the "right" and "wrong", the "external control" and "internal form of moral-self-control" (Shamsul \& Fauzi, 2006, p. 140). This explains that male dominance and female subordination are readily regulated while incest, pre-marital sex and adultery are to be prevented between men and women. This supports Gerson and Peiss's (2000) view that borders in gender relation, "construct and restrict the behaviours and attitudes of gender group while revealing the normal, acceptable behaviours and attitudes as well as deviant, inappropriate ones” (p. 120).

\section{BEING AND PERFORMING THE MASCULINITY}

The concept of borders or boundaries in this paper is also informed by the dialectic between being and performing the masculinity. Contrary to West and Zimmerman's (2000) views on "being” a gendered person in

\footnotetext{
${ }^{4}$ Khalwat (close physical proximity between unmarried Malay man and woman); Zina (premarital sex and also adultery).

${ }^{5}$ Male homosociality can be referred to as male same-sex relation or social relations between men.
} 
society where "normative conceptions and attitudes appropriate for one's sex category" (p. 132) are mandatory, the concept of being a man in Go East reveals Mahmud's desire to assert the idea of being a man in his own terms.

But the concept of performing socially endorsed male roles draws on West and Zimmerman's ideas on "doing gender" that involves "a complex of socially guided perceptual, interactional, and micropolitical activities that cast particular pursuits as expressions of masculine and feminine "natures" (p. 132). In other words, men are expected to live up to society's expectation by doing or performing the roles that help consolidate their masculine images in the public realm. This may reflect the ways in which masculinities in Asia and the Third World countries are constructed based on, for instance, indigenous knowledge and men's roles in employment and heterosexual relationship (Morrell \& Swart, 2004; Taga, 2004).

But the conflicting forces between being and performing masculinity leave men in physically and psychically damaging consequences as they are torn between the desire to be who they want to be and what they are expected to be. Mahmud sustains his heterosexual preference in his relationships with women but finds it difficult to suppress his desires for Anton. He is fully aware of the borders or boundaries with regard to his relationship with Anton but cannot help slipping into the young man's company.

It should be noted that male sexuality in Go East is readily defined by the presence and absence of homosexuality. Mahmud's desires for Anton reflect Sedgwick's (1985) views on the unbroken continuum between heterosexuality and homosexuality, particularly with regard to his relation with Anton. This provides further insights into the formation of a masculine identity that is on one hand defined by tradition and on the other fragmented by modernity.

Today, new masculine identities are formed where old values are slowly being replaced to make way for the demands of modernity. Men in the big cities may define their own masculinity that is not necessarily constrained by the borders or boundaries in their relation with women and men. 'Double lives' are invented to make way for one's desires to emotionally and sexually relate with both women and men. Although this is evident among urban and cosmopolitan men in Malaysia, there is insufficient research that can justify this recent phenomenon. 


\section{READING Go East}

Go East first appeared in Raslan's (1996) collection of short stories, Heroes and Other Stories. It mainly revolves around Mahmud's life as a planter in Eastern Sabah and his relationships with local men and women: his co-workers, female prostitutes, elderly men, an adult Javanese female maid and a young Filipino male servant. The narrative takes on the form of Mahmud's recollection of the past as he recounts his posting in Lahad Datu, Sabah. He begins by recalling how the people used to think of him, that he was this young and inexperienced person who was yet to understand why the rest of the planters left their hometowns to work in the wilderness. He eventually realized that they wanted to escape from questions, which can be read as evading social obligations.

The narrative moves on by revealing Mahmud's relationship with Jimmy Gan, an old-time planter who helped him adjust to the life on the estate. And there was Suriya, the Javanese maid that he was so physically attracted but failed in his attempt to initiate sex. He soon developed a relationship with Khalid Apong, the solid family whom he turned to for advice. But it did not last when Mahmud found that Khalid was trying to make him marry one of his daughters.

The narrative then elaborates on the intimate details of the times that Mahmud spent with Suriya and his fiancée Farida. He slept with these women but failed to sexually perform. And there was Anton, the young Filipino male servant that changed his views on his relationship with men. It is evident he was physically drawn to Anton but had to repress his desires and longings. There was a major turning point where people were aware of his relationship with Anton and this was translated in the form of a graffiti that read "Tuan sundal Anton (Tuan is Anton's bitch)". He then went back to join the workers at the club, drinking and fooling around with the prostitutes. It was not until Varna literally abused a prostitute that roused Mahmud's fear of exposing his sexual impotence. But he had passed the 'test' where he finally had sex with Tia, a thirteen year old prostitute. On the other hand, the image of making love to Anton in the process was the manifestation of his repressed sexual desire for Anton that could only take place in the mind. The narrative ends with Anton being sacked and that Mahmud finally felt that he had freed himself from problems and questions. 
Like the rest of the stories that appeared in Karim Raslan's collection of short stories, Go East offers undoubtedly rich and diverse readings. Firstly, the story could be read in its underlying theme of Mahmud's journey to self-discovery that eventually leads to his personal transformation from innocence to experience. Secondly, it could be read as an exploration of human relationships and sexuality. Karim Raslan is one of the younger generations of Malaysian writers in English that documents in his works the "changing sexual behavior of people in contemporary society" (Quayum, 1998, p. xvii) by exploring the "secrets and quirky silences of the pillars of society" through his "fictional manifestations of old and new maladies that plague contemporary Malaysia and the new Malaysia" (Fadillah et. al., 2004). It is the manifestation of borders or boundaries, and the tension between being and performing the masculinity in the story that the paper now turns.

\section{ON BORDERS, AND BEING AND PERFORMING THE MAS- CULINITY}

The manifestation of borders or boundaries is evident at the start of the narrative. Most of the planters came to Lahad Datu to "escape from questions" (p. 102), which can be read as evading repressive social roles and obligations. In other words, they wanted to free themselves from turning into the 'man' with a good job and a family. Here, rules were made and meant to be broken.

Mahmud made it clear that he did not want to be like any of the male lawyers or accountants with their "pasty, tired faces" (p. 104), a career that was highly esteemed by the Malay society at the time. He seemed to suggest that Malays were replete with obligations where social roles were endorsed and borders or boundaries were set up:

There's something nice about not having too Melayu about: they're always so disapproving - all that tak boleh, tak halus, tak manis ${ }^{6}$ - it makes me sick. We're not in an Istana any more and we carry on as if we're all courtiers or something. (p.105)

For Mahmud, the society was uncompromising where one's behaviour was subject to the 'right' and "wrong', the appropriate and acceptable as

\footnotetext{
6 “tak boleh” (inappropriate), “tak halus" (unrefined), “tak manis” (morally-behaviourally inappropriate).
} 
opposed to the inappropriate and unacceptable. This is totally the opposite of the 'borderless' world in Sabah: "[It] is a kind of relief... No family: it's a liberation” (p. 104).

However, borders or boundaries are manifest in Mahmud's relations with women (and men). He was physically drawn to Suriya but avoided sexual contacts as he was already engaged to his fiancée Farida. Admitting that he was very "prim" then, he declined the planters' invitation to "drink" and "fool around" with the prostitutes at the whore-house. He avoided the possibility of physical contacts with these women, suggesting that he was fully aware of the borders or boundaries in his relation with women.

Yet, he crossed those boundaries by eventually making out with Suriya and it was through this incident that made him aware of his impotence. This was clearly evident when he slept with Farida and Ester, a prostitute from the whore-house. He paid Ester not to tell the rest of the planters that he did not sleep with her for fear of shame and embarrassment. But he frequented the whore-house and eventually engaged in sexual activity with Tia, where he reclaimed sexual potency and overcame his anxiety over his inability to perform.

Read in Lacan's concept of subjectivity, Mahmud's anxiety is readily informed by his awareness of lack and loss in terms of male power and superiority. This is symbolic of the absence of male phallus that can be interpreted as Mahmud's inability to perform as a result of his flaccid penis. It can be said that he crossed the borders or boundaries in his relation with women through (pre-marital) sex in order to sustain his heterosexual roles. By doing this, he could overcome his fear of having his masculinity placed in a dubious and laughable state: "I was afraid that she'd (Suriya) tell the workers, that they'd laugh and make fun of me” (p. 109).

On the other hand, Mahmud's relationship with Anton offers further insights into the borders or boundaries in male same-sex relation and the dilemma between being and performing the masculinity as men relate with each other. Anton was introduced to Mahmud as Suriya's assistant. It is clear that Mahmud was and still is physically drawn to the young man's "lean body" and "powerful arms": "Even now, I can still remember tracing the line of his muscles along his arm” (p. 110).

And like his relationship with women, he was conscious of the borders or boundaries in his relation with Anton. By setting the boundaries in their employer/employee and master/servant relationship, Mahmud reminded himself not to submit to his desires. 
“I knew I shouldn't have allowed him into my bedroom but it just happened and because I wanted him there so much I was powerless to say otherwise [...]It was as if he was slipping under my skin [...]I tried slipping away from him but he was like glue; he stuck to me.” (p. 111)

He was fully aware of his 'unmanly' feelings for Anton and how this would affect his manliness in the eye of the public. He knew too well that he had crossed the boundaries and thus his decision to confront the young man face to face, "man to man".

I thought it would be better for me to establish a formal relationship between the two of us. Then at least there would be a barrier between us, something that would remind me at all times that he was a servant and a Filipino, and nothing more. In this way I'd prevent something happening, prevent the catastrophe that seemed to be about to take place. (p. 111)

But Mahmud could not break away from Anton's grip and thus failed in setting and implementing the barriers between them. He recalls "reading out Farida's old letters ... like phrases from the Koran” (p. 112) to get rid of his feelings for Anton but it did not make him feel any less for the young man.

Mahmud admits that "[he] felt needed" (p.112) as Anton confessed that he was sexually abused by one of his employers in the past. Anton also expressed his willingness to work with Mahmud forever, and eventually become a Muslim.

Unlike the symbolic absence of the phallus in Mahmud's relationship with women, Anton's willingness to serve Mahmud for life consolidates the latter's power and authority over another man. But the thought of pursuing this scared Mahmud: "[It] scared me and I was sharp with him" (p. 112). This explains heterosexual men's anxiety over the possibility of an emotionally and physically intimate relationship with other men. Phyllis Chesler (1978) found out that "a lot of men are so afraid of homosexuality that we do tremendous things to stave that possibility off" (p. 210). She adds that "it is understandable that most men shy away from vulnerable and open-ended intimacy with each other...that men deny their unrequited love for, and their fear of, other men” (p. 240). 
Mahmud's inability and incapacity for an emotional and physical relationship with Anton is partly due to his own anxiety over the homophobia of others at the plantation estate. The workers, as he mentions at the start of the narrative, "didn't want to be enlightened: they wanted confirmation...to be confirmed in what they knew" (p. 103). They took Mahmud's refusal to leave his house instead of joining them at the club as an excuse to be with Anton: "They noticed my preference I showed for Anton: Nothing was private on an estate.” They further translated their response to Mahmud's preference for Anton a "scrawled graffiti" that read "Tuan sundal Anton (Tuan is Anton's bitch)" (p. 113). It clearly revealed their views on Mahmud's 'unmanly' desires and to an extent their homophobic response to the intimacy between two men. Heterosexual men, as Peter Nardi discerned, should distance themselves from homosexual behaviours which include "emotionally close relationships with other men" for fear of being "negatively labelled homosexual" if they become too involved with another man (as quoted in Pease \& Pringle, 2001, p. 2).

The graffiti is also symbolic of Mahmud's own homophobia. To stave this off and hence sustain his manliness, Mahmud performed the masculinity by going back to the club with the 'boys' (e.g. co-workers) where he "played around with the girls, putting [his] hand up their skirts" (p. 115). It was not until Varna dragged and literally abused a Filipino prostitute in front of the workers that he realized his 'fear' for women, an emblem of his inability and incapacity for sexual intercourse: "All of the sudden, I was reminded of being in bed with Farida and Suriya. There was the same smell, the same soft, yielding flesh and my impotence, my visceral fear" (p. 116).

Read in the Freudian concept of the unconscious, it is clearly evident that Mahmud suppressed the outward manifestation of his fear of exposing his impotence in the presence of his co-workers. But it was consciously manifested in a form of hysteria where he screamed and shouted at the naked prostitute who landed on his laps after being beaten up by Varna.

It can be hypothesized that sexual potency to Mahmud is paramount in validating his manliness. His decision to find Anton after the brutality at the club can either be read as his return to homoeroticism or a means to prove that he could sexually perform or deliver. He recalls that: 
[Anton's] body seemed all the more powerful and desirable: tightly wired and ready to recoil at any moment. I looked away but turned back again. I couldn't look him in the face as I spoke; it was impossible. I knew what I wanted and I knew he wanted me to take it. (p. 117)

It was impossible because of the barriers that he had set between them: "Still I couldn't do it and he [Anton], a servant at heart, knew only how to respond and not to initiate" (p. 117). This can partly be read as Mahmud's performing his duties as an employer or master who did not want to repeat what the previous masters had done to Anton. But ultimately, Mahmud was preoccupied with the idea of intercourse. This explains Shere Hite's findings on men who enjoyed (and needed) intercourse not only for "the physical pleasure", and "psychological and emotional support" but also to validate masculinity (qtd. in Plummer, 2004, p. 84).

Mahmud's sexual triumph over Tia may have validated his manhood and sexual potency. But it was the image of Anton and how he imagined having sex with the young man that reveals his paradoxically 'true' sexual preference.

Closing my eyes and lying back on my bed, I imagined the hands were not hers but Anton's. It was all Anton: his smell, his body and cries [...] But I had performed - I had passed the test I had set myself. (p. 117)

Read in the Freudian concept of the unconscious, Mahmud's repressed homoerotic desire for Anton was only manifested in his unconsciousness. The sexual act was clearly heterosexual but his imagination was readily informed by homosexuality. It was clearly important for him to perform and become sexually potent but the conflict between being and performing the masculinity was never really resolved. Mahmud is seen to be constantly moving and shifting between being a man who has trouble relying on his genuine desires and the constant need to perform socially acceptable male roles.

His inability and incapacity for the homosexual and homoerotic reiterate Judith Butler's (as quoted in Edwards, 2004) views on how men identify their sexuality and sexual identity by (re)asserting heterosexuality and denouncing homosexuality. And by sacking Anton the following day, 
Mahmud was fully determined that he had cured his impotence. But whether or not he has found his paradoxically 'true' sexual identity remains questionable and is open for further investigation.

\section{CONCLUSION}

In conclusion, the borders or boundaries relating to male roles and bodily desires in Karim Raslan's Go East are not only sustained but also negotiated and transgressed. There is tension between being and performing the masculinity and this is reconciled through further negotiation by moving back and forth from being to performing. This raises the question of men's desire to be what they want to be and the constant need to perform socially endorsed male roles and sexual desires in order to sustain their masculine images in the public.

Mahmud is fully aware of the borders or boundaries that shape masculinity and male sexuality. He sustains, negotiates and transgresses these borders as he relates with women and men while tactfully manoeuvres between being and performing the masculinity. His inability to sexually perform with women and incapacity for an emotionally and physically intimate relationship with men reveals how he suffers from impotence and his anxiety over homoerotic desires. This provides further insights into the formation of Mahmud's male identity that is readily informed by the presence and absence of the phallus (e.g. power and superiority) as well as the presence and absence of homosexuality and homoeroticism.

It is evident that Mahmud confronted all the suffering, anxiety and fear in silence by keeping things to himself. This 'manly' nature in concealing and suppressing thoughts and feelings is worthy of investigation as it may offer insights into the ways in which men deal with silences and the subsequent effects on their state of mind, body and relations with others.

Despite negotiating and transgressing the borders and tactfully manoeuvring between being and performing the masculinity, Mahmud sustains the values relating to heterosexual male roles and sexual desires where he has passed the test that he has set himself: to become sexually potent through a sexual intercourse with women. The symbolic phallus is regained and reclaimed, and that is all the matters. 


\section{REFERENCES}

Beasley, C. (2005). Gender and sexuality: Critical theories, critical thinkers. London: Sage Publications.

Brod, H. (Ed.). (1987). The making of masculinities. London: Unwin Hyman.

Chesler, P. (1978). About men. London: The Women’s Press.

Clark, M. (2004). Men, masculinity and symbolic violence in recent Indonesian cinema. Journal of Southeast Asian Studies, 35(1), 113-131.

Connell, R. W. (1987). Gender and power: Society, the person and sexual politics. Cambridge, England: Polity Press.

Edwards, T. (2004). Queering the pitch: Gay masculinities. In M. S. Kimmel, J. Hearn, \& R. W. Connell (Eds.), Handbook of studies in men and masculinities (pp. 51-68). London: Sage.

Fadillah, M. et. al., (2004). Voices of many worlds: Malaysian literature in English. Selangor: Times Edition.

Gerson, J. M., \& Peiss, K. (2000). Boundaries, negotiation, consciousness: Reconceptualizing gender relations. In M. S. Kimmel (Ed.), The gendered society reader (pp. 118 - 131). New York and Oxford: Oxford University Press.

Hearn, J. (1987). The gender of oppression: Men, masculinity and the critique of Marxism. Brighton, England: Wheatsheat.

Raslan, K. (1996). Heroes and other stories. Singapore: Times Private.

Kimmel, M. S. (Ed.). (1987). Changing men: New directions in research on men and masculinity. Newbury Park, CA: Sage Publications.

Kaufmann, M. (Ed.). (1987). Beyond patriarchy: Essays by men on pleasure, power and patriarchy. Toronto: Oxford University Press.

Morrell, R., \& Swart, S. (2004). Men in the third world: Postcolonial perspectives on masculinity. In M. S. Kimmel, J. Hearn, \& R. W. Connell (Eds.), Handbook of studies in men and masculinities (pp. 90-113). London: Sage.

Pease, R., \& Pringle, K. (2001). A man's world? Changing men's practices in a globalised world. London: Zed Books.

Peletz, M. (1996). Reason and passion: Representations of gender in a Malay society. University of California Press: Berkeley, Los Angeles \& London. 
Plummer, K. (2004). Male sexualities. In M. S. Kimmel, J. Hearn, \& R. W. Connell (Eds.), Handbook of studies in men and masculinities (pp. 178-195). London: Sage.

Quayum, M.A. (1998). In blue silk girdle: Stories from Malaysia and Singapore. Serdang: UPM Press.

Sedgwick, E. K. (1985). Between men: English literature and male homosexual desire. New York: Columbia Press.

Shamsul, A. B., \& Fauzi, M. (2006). Making sense of Malay sexuality. jsari, 24, 140-160.

Taga, F. (2004). East Asian masculinities. In M. S. Kimmel, J. Hearn, \& R. W. Connell (Eds.), Handbook of studies in men and masculinities (pp. 129140). London: Sage.

West, C., \& Zimmerman, D. H. (2000). Doing gender. In M. S. Kimmel (Ed.), The gendered society reader (pp. 131-149). New York and Oxford: Oxford University Press. 